\title{
Discourse Analysis of the Attributions of Causality and Responsibility for the Occurrence of Leptospirosis
}

\author{
Mário Henrique da Mata Martins ${ }^{1}$ (iD) \\ Mary Jane Paris Spink ${ }^{2}$
}

\begin{abstract}
When attributing the causes and agents responsible for a public health problem, people position themselves discursively. This study aimed to analyze utterances attributing causality and responsibility for a neglected disease in Brazil: human leptospirosis. A qualitative method was adopted, using semi-structured interviews and discourse analysis by dialogical maps. Nine interlocutors participated in the study. They were indicated by managers and health professionals, considering their competence to talk about practices and experiences related to the control of the disease. Our results show five simultaneous types of attribution in the utterances, indicating variability. However, we also identified traces of discursive patterns associated with the positions occupied by interlocutors within the healthcare network. Then, we articulated a critical reflection on the potential effects of these patterns. We suggest complementary studies to be performed, associating attributions with actions aiming to reduce leptospirosis cases.
\end{abstract}

Keywords: attribution, causality, responsibility, discourse analysis, public health services

\section{Análise Discursiva das Atribuições de Causalidade e Responsabilidade pela Ocorrência da Leptospirose}

\begin{abstract}
Resumo: As pessoas se posicionam discursivamente ao atribuir causas e responsáveis por um problema de saúde pública. Este estudo teve por objetivo analisar enunciados sobre essas atribuições no que se refere a uma doença negligenciada no Brasil: a leptospirose humana. O método adotado é qualitativo, faz uso de entrevistas semipadronizadas e análise discursiva com mapas dialógicos. Participaram do estudo nove interlocutores, indicados por gestores e profissionais da área de saúde por sua competência para falar das práticas e experiências relacionadas ao controle da enfermidade. Os resultados mostraram a emergência de cinco tipos de atribuição que ocorriam simultaneamente nos enunciados, o que indica uma variabilidade atributiva. Embora haja variabilidade, é possível identificar também indícios de padrões discursivos relacionados às posições ocupadas pelos interlocutores na rede de saúde. Uma reflexão crítica sobre os efeitos potenciais desses padrões é realizada. Estudos complementares sobre a relação entre atribuições e ações para reduzir casos da doença são sugeridos.
\end{abstract}

Palavras-chave: atribuição, causalidade, responsabilidade, análise do discurso, serviços de saúde pública

\section{Análisis Discursivo de Asignaciones de Causalidad y Responsabilidad de la Ocurrencia de Leptospirosis}

\begin{abstract}
Resumen: Las personas se posicionan discursivamente en la atribución de causas y responsabilidad para un problema de salud pública. Este estudio tuvo como objetivo analizar las declaraciones de estas atribuciones con respecto a una enfermedad descuidada en Brasil: la leptospirosis humana. Se adoptó el método cualitativo, con entrevistas semiestandarizadas, y se hizo el análisis discursivo con mapas dialógicos. Participaron en el estudio nueve interlocutores designados por gerentes y profesionales de la salud por su competencia para hablar sobre las prácticas y experiencias relacionadas con el control de esta enfermedad. Los resultados mostraron cinco tipos de atribución que ocurrieron simultáneamente en las declaraciones, lo que indica una variabilidad de atribución. Aunque existe la variabilidad, también es posible identificar signos de patrones discursivos relacionados con las posiciones ocupadas por los interlocutores en la red de salud. Se reflexiona críticamente sobre el potencial de los efectos de estos patrones. Se sugieren estudios complementarios sobre la relación entre las atribuciones y las acciones para reducir los casos de la enfermedad.
\end{abstract}

Palabras clave: atribución, causalidad, responsabilidad, análisis del discurso, servicios de salud pública

${ }^{1}$ Fundação Getúlio Vargas, São Paulo-SP, Brazil

${ }^{2}$ Pontificia Universidade Católica de São Paulo, São Paulo-SP, Brazil

Article resulting from the first author's doctoral thesis, under the second author's guidance, defended in 2018, in the Graduate Program in Social Psychology of the Pontifícia Universidade Católica de São Paulo. Support: This study was funded by the Conselho Nacional de Desenvolvimento Científico e Tecnológico (CNPq - Process No.142478/2015-6).

Correspondence address: Mário Henrique da Mata Martins. Fundação Getúlio Vargas. Av. 9 de julho, 2029, Edifício John F. Kennedy, Bela Vista, São Paulo-SP, Brazil. CEP 01.313-902. E-mail: mario.martins@fgv.br
When attributing the causes of a problem and those responsible for its occurrence, people tend to position themselves discursively. Consequently, they define social actors, instruments, and tools required to step in and solve this problem. The psychological field studies this phenomenon from different approaches, all of which are interested in understanding how attributions and their respective effects are produced.

Traditionally, studies on attributions assumed a cognitive perspective, focusing on: descriptions and explanations that 
people give themselves, rational or almost rational information processing pathways whereby this process occurs, and its effects on these people's lives (Antaki, 1988). Although this is still the most dominant perspective in the field, these studies have been criticized for their method, which skews answers towards variables previously established by the researchers, and for reducing language to a vehicle that expresses cognitive processes (Edwards \& Potter, 1993).

A contemporary alternative for analyzing attribution processes is based on discursive approaches. These approaches deem attributions as products of communication and social interaction, and stress the importance of examining discursive practices and rhetorical constructions to understand how they operate and impact everyday life (Edwards \& Potter, 1993). For them, attributions do not steam from cognitive process, but rather from language use as an activity in which people position themselves, interact, and affect each other.

Considering this perspective, attributing causes and responsibilities, for example, means conveying a certain reality via positioning (Spink \& Medrado, 2013). This positioning refers to how utterances about rights and duties are associated with the social places occupied by different people acting in the world. As not every utterance can be spoken by everyone, certain attributions end up being more restricted to certain social groups, depending on the place where they are uttered. "What story-line is unfolding is mutually determined, pro has unless challenged, by the speech acts people are heard to produce, and that in turn is mutually determined by the positions that they are taken to be occupying in the episode" (Harré, Moghaddam, Cairnie, Rothbart, \& Sabat, 2009, p. 8).

For this reason, in interpreting the attribution process by a discursive perspective, one must consider people's social position during the interaction and how this position relate to the content of the attributive utterance. By examining these associations, we can identify variability and discursive patterns in several potential actions, as well as those actions more likely to be performed.

Considering these assumptions, this work sought to explore attributive processes associated with a fundamental health problem in Brazil as well as in other countries: human leptospirosis. Leptospirosis is a potentially fatal and doubly neglected tropical disease (Martins \& Spink, 2020) which occurrence is related to both behavioral (Navegantes de Araújo et al., 2013) and socio-environmental conditions (Guimarães et al., 2014). Its causative agents are bacteria, most important vectors are rats, and main signs and symptoms are fever, muscle pain (particularly in the calves), vomiting, diarrhea, and jaundice. Leptospirosis is endemic in poor urban areas in developing countries and has a high social impact, particularly in places with marked inequalities, such as Brazil (Hotez \& Fujiwara, 2014).

Recent scientific literature on leptospirosis has primarily explored the socio-environmental conditions for its incidence in different Brazilian regions (Felzemburgh et al., 2014;
Guimarães et al., 2014) and the diagnostic and therapeutic advances over recent years (Conceição, Andrade, \& Louzada, 2013). However, studies on psychosocial dimensions associated with ways of preventing and controlling human leptospirosis are still scarce (Navegantes de Araújo et al., 2013), and studies on attributions of responsibility and causality to the disease have not yet been performed. Considering that, this study aimed to analyze utterances attributing causality and responsibility for a neglected disease in Brazil: human leptospirosis.

A discourse analysis on attributions associated with a public health problem such as leptospirosis enable us to identify who and in which social position owes the power to attribute rights and duties and causes and responsibilities, as well as the presented pathways to solve this problem. We expect this study to contribute to the theoretical field of studies on attributions, as well as to the field of public policies, by enabling further studies to address the psychological implications entailed in producing and facing a public health problem by the analysis of attributive processes.

\section{Method}

This research adopted a qualitative method for producing information, performing discourse analysis, and discussing the results.

\section{Participants}

This study was composed by nine interlocutors directly associated with the management, monitoring, diagnosis and/or treatment of human leptospirosis in a Brazilian municipality, users of the healthcare system, and that have had the disease. Inclusion criterion was the indication by managers and technicians responsible for monitoring human leptospirosis in the municipality. Participants' identities were kept confidential.

\section{Instruments}

Semi-structured interview questions. The interview was composed of three questions that sought to explore: interlocutor's position within the healthcare network; which causalities they attributed to leptospirosis; and who they believed to hold responsibility. The questions were: "What is your professional/personal relationship with cases of leptospirosis?", "Why does leptospirosis exist today?", and "Who is responsible for the occurrence of leptospirosis?" Complementary questions were asked when needed. The interview was handled as a process of negotiating meaning, in which both the researcher and interviewees jointly produced information (Aragaki, Lima, Pereira, \& Nascimento, 2014). They were conducted by an interviewer with all participants, respecting the speech time, and with specific interventions to return to the addressed object. 


\section{Procedures}

Data collection. Interviews were conducted with all participants, at their preferred time and place, recorded in audio, upon their authorization, and transcribed later. For transcription, two procedures were adopted: firstly, a sequential transcription, in which the interviewer took note of the themes addressed by each participant; then, all content addressed in the communicative process was fully transcribed (Spink, 2013). Jefferson's conventions for transcribing (2004) were adapted and applied into transcription. This article does not apply the transcription symbols in the presented excerpts due to publication norms. However, if necessary, succeeding paragraphs will discuss moments in which the phenomena of rising tone, laughter, and interrupted speech occurred.

Data analysis. Once all interviews were transcribed, a dialogical map was used to identify common attributions of cause and responsibility among interviewees and unravel researcher's interventions. Dialogical maps differ from thematic maps because the first assumes that researchers' questions and interactions must necessarily be contained in the analysis, for being part of the dialogical process (Nascimento, Tavanti, \& Pereira, 2014).

From these maps, we selected discursive interactions in which participants attributed causality and/or responsibility for the occurrence of leptospirosis. Then, common attributions and their respective justifications were identified among participants to construct thematic categories. Next, the themes addressed by the nine interviewees in their explanations for the occurrence of the disease were identified. These themes grounded the construction of the dialogical map for each discursive interaction selected from the interviews, as Table 1 exemplifies.

Finally, speeches contents were replaced using the graycolored shading option of the Microsoft Word 2010 software. At first respecting the discourse flow to enable the display of dialogue sequences and dynamics of thematic changes. Later, the thematic categories of each interviewee were synthesized to obtain an overview of the relationship between positioning and themes addressed in the attributions (Spink, 2013).

\section{Ethical Considerations}

This study was approved by the Research Ethics Committee of the Pontificia Universidade Católica de São Paulo (Opinion No. 846.510, CAEE No. 37203114.8.0000.5482)

\section{Results and Discussion}

Our results show that the analyzed utterances present both variability and attributive patterns. An example of variability is found in the speech of a user of the healthcare system who have had leptospirosis.

$\mathrm{R}$ - Why does leptospirosis exist today?

I - I believe it is mostly because of public health too, right? Yes, sanitation, it is really associated with the su- burbs. The disease. And the lack of information, quite often, right? Perhaps many people that have contact with water have no idea that there he can contract diseases, and ends up slacking off. It's mostly due to the lack of information and public health, isn't it? (Interview 1)

Although cognitive-biased studies on attributions of causality and responsibility favor approaches with clear attributions made by the interlocutor, daily utterances tend to be much more contradictory (Wetherell \& Potter, 1992). The user of the speech above mentions not only one attribution of causality, but three: poor sanitation that affects public health, social classes that affects the use of a space "associated with the suburbs," and - with a rising tone - the lack of information.

Such attributions of causality imply, directly or indirectly, distinct attributions of responsibility: the first holds the governmental sectors responsible, which should ensure adequate sanitation for the population; the second blames a social structure that segregates and defines who gets to be exposed to the disease according to the place they live in; and the third directly blames people vulnerable to the disease, who "end up slacking off." Thus, a single utterance present not only one positioning, but different positions grounded on attributive processes that are also different.

However, these positioning are not only distinct. Interlocutors seek to produce meaning in this variability (Wetherell \& Potter, 1992). In this specific case, the interlocutor sought to hierarchize the priorities. After presenting the initial factors, a rising tone suddenly occurs, indicating that the upcoming attribution - the lack of information - plays a key role. This hierarchy is more prominent at the end of the speech, when the user applies the term "mostly." Although differing, the interlocutor seeks to privilege one attribution over others.

The presented utterance denotes how attributive positioning and processes vary, and interlocutors try to establish patterns for this variability. The next example has a hierarchical pattern. However, the excerpts in Table 1 show the sequential pattern established by the interlocutor: the lack of sanitation leads to the presence of sewage, the community itself does not take responsibility for it and disposes waste in inappropriate location; that way, the presence of sewage and waste attracts rats. This exemplifies that even patterns may vary within utterances.

For this reason, we compared the different utterances of the nine interlocutors. The most common pattern related the types of attribution to the interlocutor's position within the healthcare network. Attributions of causality owing to political issues, urban infrastructure, and some inoperative healthcare services were predominant among managers and health professionals. Attributions of causality to the presence of rats were predominant among users of the healthcare system, and the lack of information and education was indistinctly mentioned among different social positions. We also identified that attributions of responsibility follow the shapes of attributions of causality. 
Table 1

Dialogical map of an interview excerpt conducted with a health system operator

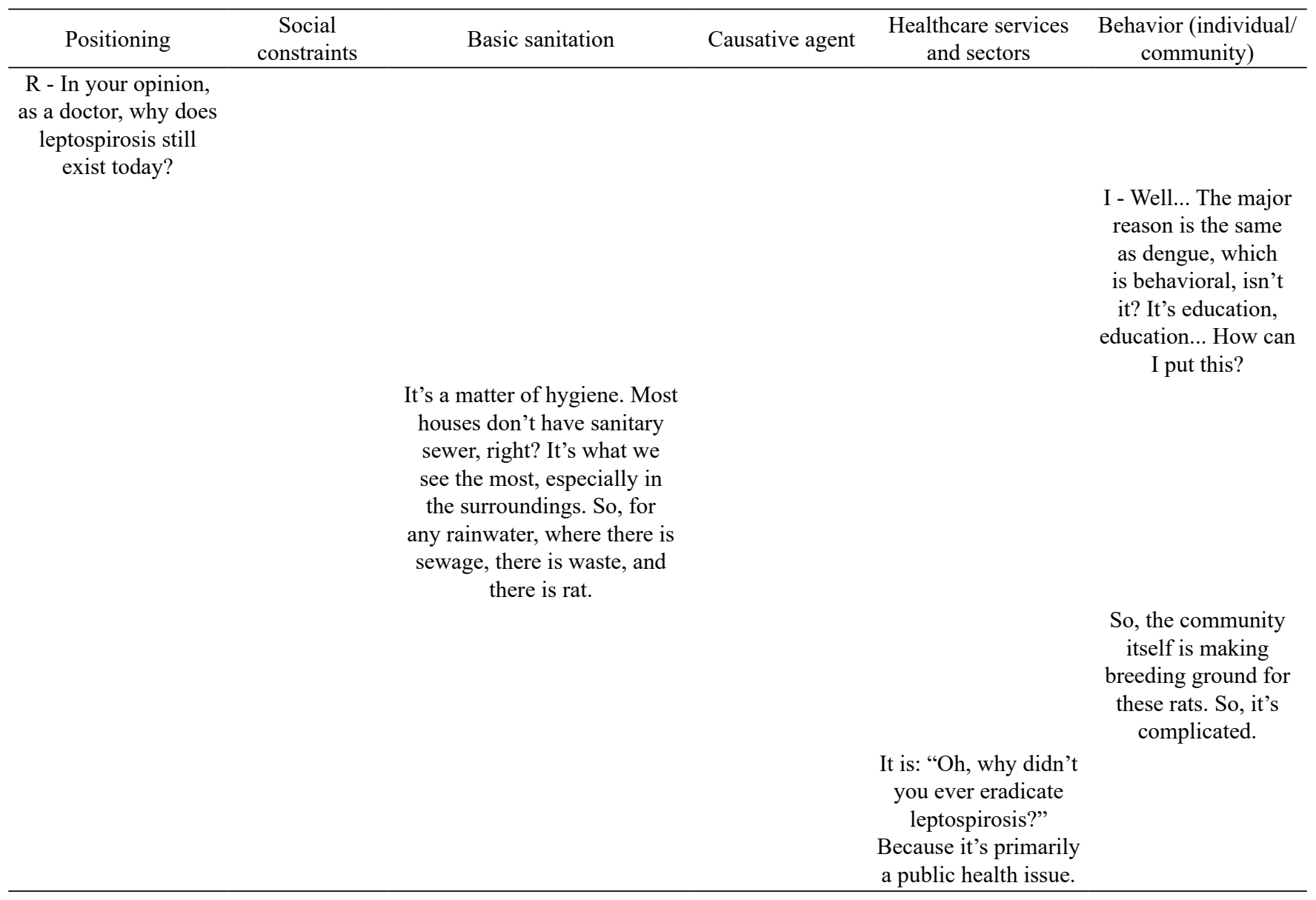

Note. $\mathrm{R}=$ Researcher who conducted the interview; I = Interlocutor participating in the research; Interview conducted with a health professional, responsible for attendance and diagnoses of leptospirosis cases.

\section{Political issues, urban infrastructure, and inoperative healthcare services}

These themes were addressed by interlocutors who occupied a management or medical position in the reference hospital for the treatment of severe leptospirosis. They present a broad vision of the leptospirosis problem, either because of their professional position or training, understanding it from the political, social, and structural conditions of the country, as expressed by a manager associated with epidemiological surveillance.

$\mathrm{R}$ - So, I keep wondering, then why does it exist in Brazil?

I - Yes. Particularly because I have a Social Work background, right? So we must realize the social issue. It's like you said about social vulnerability being an aggravating factor. And we know that there are huge conditions of inequality, right? So this is why it exists. Because: I believe it's not a disease that affects the wealthiest populations. I don't know, the ruling class. I believe it's pretty much it. That there's no such...
Like tuberculosis, right? Tuberculosis is a disease of poverty, just as leptospirosis is a disease of poverty. Different from dengue. (Interview 1)

The interlocutor justifies her focus on the social issue of leptospirosis based on her academic background. She also spontaneously compare leptospirosis to other diseases marked by interrupted speech and rising tone - to exemplify its occurrence among poverty. Besides this manager, a healthcare system operator working at the reference hospital for the treatment of severe leptospirosis also mentions the social conditions of the country when referring to the occurrence of the disease. "I - The impression it conveys is... the social conditions of underdeveloped countries, and terrible social conditions... It looks like a disease that is related to the social condition of the country. To the Third World social condition in which we live in. To an underdeveloped country, which is our case" (Interview 4).

The interlocutor of the previous excerpt points the social conditions and lack of development of a country as key factors for the occurrence of leptospirosis. The rising tone in the term "terrible" outlines the nature of these conditions. 
The utterances of the manager and this healthcare operator apply terms such as: vulnerability, social inequality, poverty, poor social conditions, underdeveloped country, and Third World. By doing this, they draw a framework in which leptospirosis is caused at a macrostructural societal level, and responsibility for its occurrence cannot be directly indicated - the overall society is responsible for this situation.

Six interviews approached the themes of poor basic sanitation and its impacts on public health. Yet, they were prominent only among managers and healthcare professionals. A healthcare system manager sought to illustrate this problem by stating the basic sanitation scope within the municipality in which she operates.

I- So... So, because we have, in the city, as you pointed, we have only $40 \%$ of sanitation, isn't it?

$\mathrm{R}$ - Less, I guess, than $40 \%$.

I - It's less than $40 \%$. I haven't checked the water and sewer company's website, so I can't say that, right? But we were talking about it. (Interview 1)

The manager resumes the percentage data presented by the researcher earlier in the interview to apply them into her argument, which expatiated on basic sanitation as the cause for the reduced incidence of human leptospirosis. She argues that sanitation is insufficient, which increases the number of cases of leptospirosis. Influenced by her previous dialogue with the researcher, she applies the data in her discourse, elucidating that the responsibility for their accuracy - marked by interrupted speech, as her affirmation was denied - is not exclusive hers, but shared with the researcher.

Such argument is reiterated by yet another healthcare professional, who associates it with class distinctions and political interests that function as criteria for the existence (or not) of sanitation in a certain territory of his municipality.

$\mathrm{R}$ - And a question of a more social scope, we also discussed a little about the...

I - Uh?

Q - The causes of leptospirosis, why does it still exists. I wanted to know from you, in your opinion, why does leptospirosis still exist?

I- Unfortunately, because of basic sanitation. You can see that... that we don't really see leptospi... unfortunately or fortunately, we don't see leptospirosis in upper-class neighborhoods. Why? Because they have sewage, basic sanitation. It's part of the wealthiest population, it's a little more demanding, or there are politicians living within this neighborhood. And, unfortunately, we see that in the humblest neighborhoods politics only appears during election periods. (Interview 5)

The professional stresses - marked by laughter - that sanitation is present in places where politicians live, but lacks in other areas, where poorer people live. In this case, laughter superimposes the interviewee's meanings when revealing a problem (Grønnerød, 2004), denouncing a grotesque situation and attributing responsibility to the politicians. They are the primarily responsible for defining where and how sanitation and infrastructure works will be performed in the city, live in the best area of the municipality in which the interviewee works, and have access to sanitation services. These factors imply that politicians use their privileged political position for obtaining benefits that should be distributed throughout the population that elected him. The correlation between public investments and rulers' places of residence was previously discussed in the literature as a factor of interest for analyzing determinants of neglected diseases (Hotez, 2008).

If diseases such as leptospirosis are associated with structural issues - such as poverty, social inequalities, and environmental issues, as lack of basic sanitation, - then healthcare operations would have much to be done. This issue was mentioned by three interviewees associated, somehow, with healthcare planning.

A professional responsible for the health information technology sector addresses several aspects of the issue related to professionals' lack of preparation in actions of anticipation. She clarifies that, if there is a likelihood of heavy rainfall and flooding, then the incidence of leptospirosis will certainly increase, which would require a preparation from the healthcare system.

I - Two years earlier, Santa Catarina had had a flood, in which there were 3,000 new cases of leptospirosis. Do you know how many deaths there were? Not a single. Alagoas, in 2010, I guess they had less cases of leptospirosis. But we had two deaths owing to the disease. Population living conditions associated with a deficient healthcare service. Because they didn't think, right? They didn't have a strategy, at that moment, to avoid. Then, after that - we shout a lot: "No, we have to go down, we have to make these doctors think," right? [Think] that after flooding, we will have [cases]. And they have to suspect of the disease before people die. You see? (Interview 9)

The interlocutor draws attention to the influence of health sector planning on mitigating or eradicating the number of deaths due to leptospirosis. Understanding planning as a process requires to think of it articulated to management (Rivera \& Artman, 2012), and perhaps that justifies why only professionals associated to management expressed such attribution.

\section{Rats and rodent control}

These themes were addressed by professionals from epidemiology and users of healthcare services. Rats, particularly, are ubiquitous among the discourses and considered the causative agents of leptospirosis. Their presence increases with waste, floods, flooding, and lack of sanitation. A user of healthcare services who had leptospirosis applied his personal experience by attributing the causality and responsibility for the disease to the proliferation and infestation of these vectors. 
$\mathrm{R}$ - From what you got to know and feel within the healthcare network, why do you think leptospirosis exists today?

I - From studies!

$\mathrm{R}$ - No, no! Why does it exist in terms of disease? Why does this disease still exist today? In your opinion?

I - In my opinion... rat epidemic [infestation].

$\mathrm{R}$ - Because of rat epidemic [infestation].

I - Yes, because of rat epidemic [infestation]. Because at my mom's house, it's a big house I told you about last time, there's a lot of dogs. So, if you feed the dogs and the leftovers stay there all night, I guess the dogs, the rats come along. Because two of her dogs have died due to leptospirosis. (Interview 7)

Participants who mentioned the disease vectors attributed to them its causality and to the environmental sector the responsibility for controlling it. This double attribution and interconnection between factors leads to a discourse that places intervention outside the health sector, but in the environmental control of rats. Studies on the field indicate that the sectorization of health, sanitation, development, and environment not only divided activities, but created exclusivity of competencies within sectors, hindering joint action (Souza, Costa, Moraes, \& Freitas, 2015).

\section{Attributions of responsibility to vulnerable people}

Besides rats and environmental control sectors, people in situation of vulnerability to leptospirosis were also considered responsible for the disease. Among the nine interviewees, six mentioned aspects associated with population responsibility for the continued presence of leptospirosis in the Brazilian public health scenario.

The educational issue may be implied within the cultural practices and socioeconomic conditions of populations affected by leptospirosis, as addressed by a health professional working at the reference hospital for the treatment of severe leptospirosis: "I - Terrible hygiene. Patient's profiles are... it's homogeneous, it's... they pertain to lower-classes, with bad hygienic conditions, including their bodies" (Interview 4). The interviewee indicates the issue of structural social classes as a factor that hampers the combat of leptospirosis whilst emphasizing - in a lower tone - the lack of personal hygiene among users treated with leptospirosis. In doing this, he attributes responsibility to this body that he is ashamed to mention, which must be pronounced confidentially, lowering the voice tone.

This is also evident in the speech of a physician from a reference hospital for the diagnosis of leptospirosis, who correlates certain behaviors that promote rats proliferation with the lack of education of the population: "I - Well, the major reason is the same as dengue, which is behavioral. Isn't it? It's education, education... how can I put this? So, the community itself is making breeding ground for these rats. So it's complicated" (Interview 3).

Yet, the technician responsible for monitoring cases is the main interviewee to attribute the causality of leptospirosis to the lack of information and education of the population, and the responsibility for the disease to users of the healthcare service. This professional has monitored the population daily, even before a diagnosis was formulated.

I - A time ago, a long time ago, we did an awareness-raising activity on the grotas. We went to a grota. People from the urban cleaning service were cleaning the... the manhole, right? The sewage. And... We went to houses, raising awareness on waste accumulation, to prevent leptospirosis, dengue and everything. The neighbor said she simply wouldn't throw her trash into the container, that there was already a container in there so that people wouldn't throw it in the ditch, back there, simply because she said "what's the point of me throwing it there while my neighbor throws it in here? So I throw it in here too." [...] You see, because of what? Mostly because of the population! We went there, we had leaflets on leptospirosis, waste. We gave everything to the population, explaining, doing an educational work. We were doing it over, and the staff doing all the cleaning, so that from that moment on the population would be aware about throwing garbage in the container, because there is a container in there. And, if you walk past there, sometimes it's empty, but try looking at the ditch. It's full. You see? That's it. How is leptospirosis going to, not end, but fall in index? Never. (Interview 8)

Initially, the technician stresses - with a rising tone - that the awareness-raising activity was performed a long time ago. For a reason, which he will state later, it had no continuity in subsequent years: a resident's speech discouraged the work they performed. In assuming the voice of the resident, who refuses to dispose waste properly because her neighbor maintains an inappropriate habit (Corrêa \& Ribeiro, 2012), the technician attributes responsibility to the population for the waste issue, which, for him, is directly associated with leptospirosis.

Yet, some people reflect critically upon the subject, considering that emphasizing education as a way of solving this issue leads to a circularity within educational needs.

I - Well... there is no education, we don't have enough education for this to happen: the cleaning, understanding that we need. Then, it's also a little about people not wanting to, too, right? To play their role on it, because they have no education. Well, it's the... It's the vicious circle again. (Interview 2)

Education is not simply information. It is a broader aspect comprising deficiencies within the education systems, cultural aspects, and a willingness for collaboration from the population. These interlocutors have attributed the responsibility for the occurrence of the disease to the population, either for the lack of information, education, and hygiene, or for their cultural practices, which promote contact with unhealthy environments, rats proliferation, and inadequate waste disposal. However, the manager's speech is substantial - part of the responsibility is 
indeed of the population, which fosters discussions on various attributions of causality, responsibility, and action. It is not an isolated management action, but rather a control that considers the different dimensions of attributions of causality and responsibility, including (although not exclusively) the affected population.

Our research demonstrates that the position occupied by people within the healthcare network may influence how they attribute responsibility and causality to a health issue. Attributions may have concrete implications in management processes and in defining the measures to be adopted for disease control. The discursively-stated measures were: implementing infrastructure interventions for installing local sanitation systems in high-incidence areas; using rodenticides in areas of high rat proliferation; creating strategies and preventive and preparative plans for periods preceding an increase in case numbers, and educational campaigns to raise population awareness. Attribution implicates not only defining an opinion, but also a potential field of intervention.

The adopted transcription code allowed us to visualize the effects of laughter and volume and vocal tone changes in producing information. Common laughter denounces problems with public policy management in the interviewees' opinion. In turn, volume and vocal tone changes drew attention to used keywords, by stressing and accentuating them, and also delineated relevant moments. Such notes reiterate the importance in adopting these codes in discursive analysis, as they allow the identification of phenomena that, without this methodological strategy, would not be analyzed.

From a theoretical approach, our study sought to corroborate studies on attributions by presenting different analysis techniques and strategies that contemplate elements that are potentially neglected by the traditional analysis model. Yet, the adopted model impose some limitations. The common themes found cannot be generalized. Our research has a qualitative nature and focuses specifically on the discourse of nine participants, hindering generalizations. Another limitation is the impossibility in categorically stating that such attributions necessarily imply that certain measures, grounded on them, will be adopted. This would require further studies aiming to understand the proposed actions to solve the issue of leptospirosis, according to the author's respective attributions.

\section{References}

Antaki, C. (1988). Explanation, communication and social cognition. In C.Antaki(Ed.), Analysing everyday explanation: A casebook of methods (pp. 1-14). Beverly Hills, CA: Sage.

Aragaki, S. S., Lima, M. L. C., Pereira, C. C. Q., \& Nascimento, V. L. V. (2014). Entrevistas: Negociando sentidos e coproduzindo versões de realidade [Interviews: Negociating meanings and coproducing version of reality]. In M. J. Spink (Org.), A produção de informação na pesquisa social: Compartilhando ferramentas [Information production in social research: Sharing tools] (pp. 57-72). Rio de Janeiro, RJ: Centro Edelstein de Pesquisas Sociais.
Conceição, K. S., Andrade, M. G., \& Louzada, F. (2013). Zero-modified Poisson model: Bayesian approach, influence diagnostics, and an application to a Brazilian leptospirosis notification data. Biometrical Journal, 55(5), 661-678. doi:10.1002/bimj.201100175

Corrêa, G. T., \& Ribeiro, V. M. B. (2012). Dialogando com Bakhtin: Algumas contribuições para a compreensão das interações verbais no campo da saúde. [Dialogue with Bakhtin: Some contributions to the understanding of verbal interactions in the health field]. Interface: Comunicação, Saúde, Educação, 16(41), 331-342. doi:10.1590/S1414-32832012005000023

Edwards, D., \& Potter, J. (1993). Language and causation: A discursive action model of description and attribution. Psychological Review, 100(1), 23-41. doi:10.1037/0033295X.100.1.23

Felzemburgh, R. D., Ribeiro, G. S., Costa, F., Reis, R. B., Hagan, J. E., Melendez, A. X., ... Ko, A. I. (2014). Prospective study of leptospirosis transmission in an urban slum community: Role of poor environment in repeated exposures to the Leptospira agent. PLoS Neglected Tropical Diseases, 8(5), e2927. doi:10.1371/ journal.pntd.0002927

Grønnerød, J. S. (2004). On the meanings and uses of laughter in research interviews: Relationships between interviewed men and a woman interviewer. Young: Nordic Journal of Youth Research, 12(1), 31-49. doi: $10.1177 / 1103308804039635$

Guimarães, R. M., Cruz, O. G., Parreira, V. G., Mazoto, M. L., Vieira, J. D., \& Asmus, C. I. R. F. (2014). Análise temporal da relação entre leptospirose e ocorrência de inundações por chuvas no município do Rio de Janeiro, Brasil, 2007-2012 [Temporal analysis of the relationship between leptospirosis and the occurrence of flooding due to rainfall in the city of Rio de Janeiro, Brazil, 20072012]. Ciência \& Saúde Coletiva, 19(9), 3683-3692. doi:10.1590/1413-81232014199.06432014

Harré, R., Moghaddam,F.M., Cairnie, T.P., Rothbart, D., \& Sabat, S. (2009). Recent advances in positioning theory. Theory \& Psychology, 19(1), 5-31. doi:10.1177/0959354308101417

Hotez, P. J. (2008). Forgotten people, forgotten diseases: The neglected tropical diseases and their impact on global health and development. Washington, DC: ASM Press.

Hotez, P. J., \& Fujiwara, R. T. (2014). Brazil's neglected tropical diseases: An overview and a report card. Microbres and Infection, 16(8), 601-606. doi:10.1016/j. micinf.2014.07.006

Jefferson, G. (2004). Glossary of transcript symbols with an introduction. In G. H. Lerner (Ed.), Conversation analysis: Studies from the first generation (pp. 13-31). Amsterdam, The Netherlands: John Benjamins. 
Martins, M. H. M., \& Spink, M. J. P. (2020). Human leptospirosis as a doubly neglected disease in Brazil. Ciência \& Saúde Coletiva, 25(3), 919-928. doi:10.1590/1413-81232020253.16442018

Nascimento, V. L. V., Tavanti, R. M., \& Pereira, C. C. Q. (2014). O uso de mapas dialógicos como recurso analítico em pesquisas científicas [The use of dialogic maps as analitic resource in scientific research]. In M. J. P. Spink, J. I. M. Brigagão, V. L. V. Nascimento, \& M. P. Cordeiro (Orgs.), A produção de informação na pesquisa social: Compartilhando ferramentas [Information production in social research: Sharing tools] (pp. 247-272). Rio de Janeiro, RJ: Centro Edelstein de Pesquisas Sociais.

Navegantes de Araújo, W., Finkmoore, B., Ribeiro, G. S., Reis, R. B., Felzemburgh, R. D., Hagan, J. E., ... Costa, F. (2013). Knowledge, attitudes, and practices related to Leptospirosis among urban slum residents in Brazil. American Journal of Tropical Medicine and Hygiene, 88(2), 359-363. doi:10.4269/ajtmh.2012.12-0245

Rivera, F., \& Artmann, E. (2012). Planejamento e gestão em saúde: Conceitos, história e propostas [Health, planning and management: Concepts, history and proposals]. Rio de Janeiro, RJ: Ed. FIOCRUZ.

Souza, C. M. N., Costa, A. M., Moraes, L. R. S., \& Freitas, C. M. (2015). Saneamento: Promoção da saúde, qualidade de vida e sustentabilidade ambiental [Sanitation: Health promotion, quality of life and environmental sustainability]. Rio de Janeiro, RJ: Ed. FIOCRUZ.

Spink, M. J. P. (2013). Ao sabor dos riscos: Reflexões sobre a dialogia e a coconstrução de sentidos [Following risks: Reflections on dialogy and meaning co-construction]. In M. J. P. Spink (Org.), Psicologia social e saúde: Práticas, saberes e sentidos [Social psychology and health: Practices, knowledges and meanings] (pp. 295-323). Petrópolis, RJ: Vozes.

Spink, M. J. P., \& Medrado, B. (2013). Produção de sentido no cotidiano: Uma abordagem teórico-metodológica para análise das práticas discursivas [Meaning production in daily life: A theoretical and methodological approach to discursive practices analysis]. In M. J. Spink (Org.), Práticas discursivas e produção de sentidos no cotidiano: Aproximações teóricas e metodológicas [Discursive practices and meaning production in daily life: Theorethical and methodological approaches] (pp. 22-41). Rio de Janeiro, RJ: Centro Edelstein de Pesquisas Sociais.

Wetherell, M., \& Potter, J. (1992). Mapping the language of racism: Discourse and the legitimation of exploitation. New York, NY: Columbia University Press.
Mário Henrique da Mata Martins is a Researcher of the Fundação Getulio Vargas, São Paulo-SP, Brazil.

Mary Jane Paris Spink is a Professor of the Pontifícia Universidade Católica de São Paulo, São Paulo-SP, Brazil.

Authors' Contribution:

All authors made substantial contributions to study conception and design, data analysis and interpretation, and to manuscript revision and approval of the final version. All the authors assume public responsibility for content of the manuscript.

Received: Jun. 29, 2018

1st Revision: Dec. 07, 2018

2nd Revision: Jun. 09, 2019

Approved: Dec. 22, 2019

How to cite this article:

Martins, M. H. M., \& Spink, M. J. P. (2020). Discourse analysis of the attributions of causality and responsibility for the occurrence of leptospirosis. Paidéia (Ribeirão Preto), 30, e3027.doi:https://doi.org/10.1590/1982-4327e3027 